Vol.8, Issue 2, pp.22-30, February 2020

Published by ECRTD- UK

Print ISSN: ISSN 2054-6351

Online ISSN: ISSN 2054-636X

\title{
PRELIMINARY EVALUATION OF STUDENT APPROACHES TO LEARNING IN MOROCCAN CONTEXT
}

\author{
Omar Jiyed ${ }^{1}$, Asma Id Babou', Bouchta El Batri', Maskour Lhoussaine ${ }^{1}$, \\ El Mostapha Aouine ${ }^{2}$, Anouar Alami ${ }^{1 *}$ and Moncef Zaki ${ }^{1}$ \\ ${ }^{1}$ Interdisciplinary Research Laboratory in Didactics of Science and Technology, \\ LIRDIST, Faculty of Sciences Dhar El Mahraz, Sidi Mohammed Ben Abdellah \\ University, P.B. 2626, Fez 30000, Morocco. \\ ${ }^{2}$ Applied Human Sciences Laboratory, Faculty of Letters and Human Sciences, Sais- \\ Fes, Sidi Mohammed Ben Abdellah University, P.B. 2626, Fez 30000, Morocco \\ *Corresponding author: E-mail: anouar.alami@usmba.ac.ma
}

\begin{abstract}
One of the main factors influencing the quality of learning and therefore the success of students are the Student Approaches to Learning (SALs). They are the why (the motivation) and the how (the strategy) of learning. This transversal study was conducted for the first time in a Moroccan open access university context. Using our validated Arabic version of the revised two-Factor Study process questionnaire $(R-$ $S P Q-2 F$ ), the aim of this study was first, examining the overall SALs (Deep Approach, DA and Surface Approach, SA) among a tertiary context in Morocco. Second, assessing and examining the variance of DA and SA scores when related to two personal factors, namely gender and study levels. This study was conducted within the Faculty of Science Dhar El Mahraz (FSDM) belonging to the University Sidi Mohammed Ben Abdellah (Fez-Morocco) among 300 Moroccan students (138 females) enrolled in different programs across three levels of study (2ed, 4th and 6th Semester). An ANOVA and a ttest were performed. The results showed a significant difference between the two factors. In conclusion, the use of SALS in teaching evaluation is important for the university community to promote the factors influencing deeper learning. Other factors must therefore be explored.
\end{abstract}

KEYWORDS: SAL, deep approach, surface approach, gender, study level.

\section{INTRODUCTION}

The reform adopted by the Moroccan higher education system in particular since the introduction of the National Charter for Education and Training and the Law No. 0100 in the early 2000s and the Strategic Vision 2015-2030 ( CSEFRS, 2015) has put the quality of learning at the heart of the objectives of any educational action and focused on active learning. Furthermore, improving the quality of learning requires understanding the ways in which students experience the learning environment (Hall et al., 2004; Ramsden \& Entwistle, 1981; Willcoxson, 1998) in other words their Approaches to Learning (AL). In fact, Knowing Student Approaches to Learning (SALs) may be used as feed-back and evaluation mean by institutions of higher education (Wilson et al., 1996; Biggs et al., 2001)). This feedback can shed a led to a 
Vol.8, Issue 2, pp.22-30, February 2020

Published by ECRTD- UK

Print ISSN: ISSN 2054-6351

Online ISSN: ISSN 2054-636X

discussion in favor of certain aspects of effective teaching and deep learning within the academic community (Biggs, Kember, Leung, 2001).In Morocco, to our best knowledge and following our bibliographical research, the ways in which students approach their learning have not yet had a part of study. In addition, no studies have addressed the influence of certain factors on these approaches and especially at openaccess public universities.

\section{THEORETICAL FRAMEWORK}

This study was constructivism framework-based. The latter is called to contextualize the learning experience as it focuses on the students' ways of going about their tasks. In fact, the Biggs's 3P Model of teaching and learning (Presage, Process, Product) is a good representation of constructivism and focuses on a single domain witch is "student learning". As a theoretical framework for this research, the model as described by Biggs $(1993,1999)$ is a succession of three sequences as shown in figure 1: Sequence 1: Presage is the prior of learning task where, in one hand, personal factors such as prior knowledge, motivation, personality, abilities, values, characteristics of the student, level of study and so on, and on the other hand, the contextual factors related to the learning environment ,namely curriculum content, workload, the teaching practices, assessment methods, classroom climate and so on, may act individually or in combination on the Process level.

Sequence 2: The Process: it is the "inside" of the learning task where one can distinguishes the "why" (intentions) and the "how" (strategies) that students can undertake in the task in other words, SALs. (see details below). The process sequence is clearly influencing the learning outcomes (i.e. the product). Although the model looks sequential but there is always an inter-sequential feedback which makes it an open system. The process level (SALs) remains at the heart of the 3P model and that Biggs et al., (2001) describes as being at the heart of the teaching and learning system. It is at this process level that the activity related to learning may produce or not produce the desired result (Biggs et al., 2001)

Sequence 3 the product: this is the post learning result obtained from learning. These outcomes or performance could be qualitative in terms of skills and life goals as it could be quantitative measured by the evaluation of acquired knowledge in exam and tests and projects. Except It is important to note that this 3P model According to Biggs (1999) this model acts as a system. 


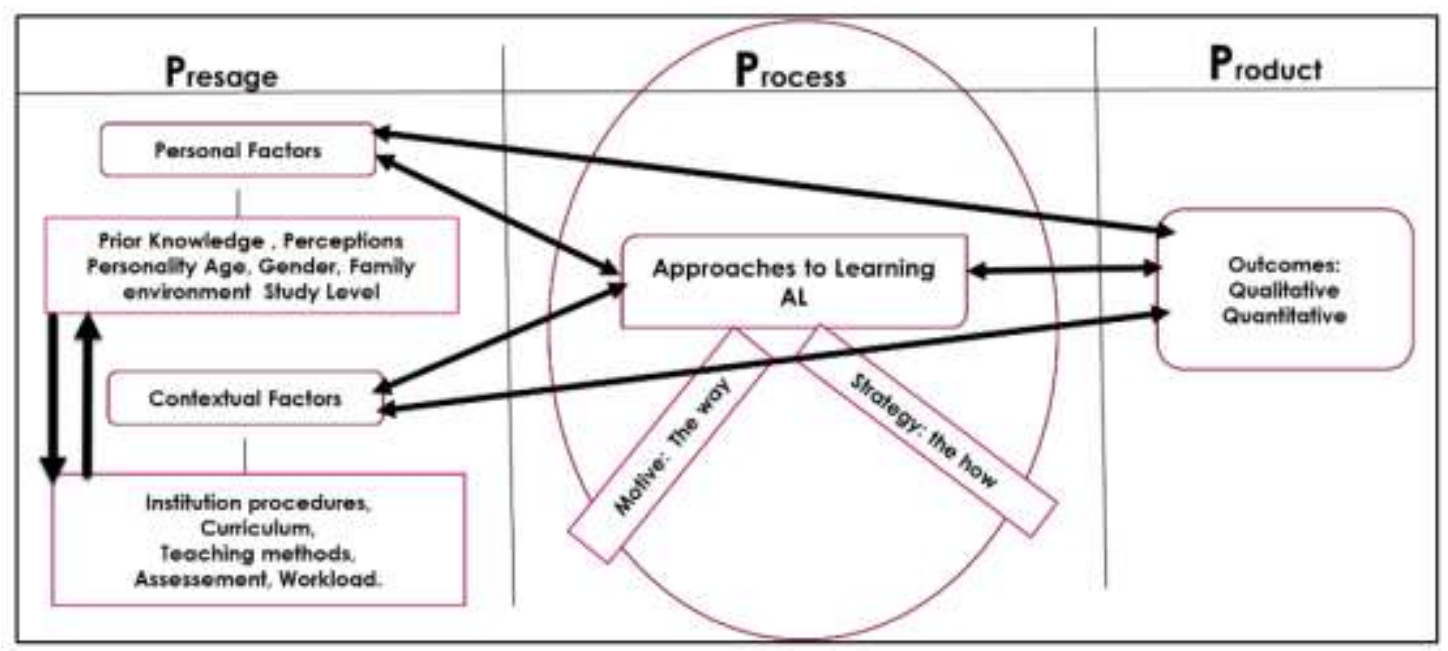

Figure 1. The 3P model from (Biggs et al., 2001) used with Biggs's permission.

\section{Approaches to Learning}

The history and the development of these approaches started with phenomenographical method in the seventies with Marton and Säljö work (1976) and resulted in defining two fundamental approaches that students adopt in their learning: The Deep Approach (DA) and the Surface Approach (SA). Their study was the first to take this approach and provide a classification student learning. Further, several studies, but this time in analytical way and on the basis of theoretical literatures in cross-cultural contexts lead to the same concept of SALs (Biggs, 1987; Entwistle et al., 1979). To assess and quantify these approaches several instruments were developed (e.g., Approaches and Study Skills Inventory for Students (ASSIST) (Tait et al., 1998) that derived from the Approaches to Studying Inventory (ASI) (Entwistle \& Ramsden, 1983). In this study we used the newest version of Study Process Questionnaire (SPQ) (Biggs, 1987): The R-SPQ-2F (Revised Two-Factors Study Process Questionnaire) witch is the revised and the short form of the SPQ (Biggs et al., 2001). This tool classifies and categorizes students in dichotomous scales, namely the two approaches DA and SA with motive (indicating the why) and strategy (indicating the how) subscales each. Table 1 gives an overview of the instrument scales.

Table 1.Approaches to learning overview and features.

\begin{tabular}{|l|l|l|}
\hline & Motive (Why) & Strategy (How) \\
\hline Deep Approach & $\begin{array}{l}\text { Deep Motive: Intrinsic interest } \\
\text { in what is being learned; } \\
\text { develop competence particular } \\
\text { subjects/courses }\end{array}$ & $\begin{array}{l}\text { Deep strategy: Discover } \\
\text { meaning by large reading, } \\
\text { Make interrelationship } \\
\text { with previous relevant } \\
\text { knowledge etc }\end{array}$ \\
\hline Surface Approach & $\begin{array}{l}\text { Surface motive: Meet } \\
\text { requirements at the minimum; } \\
\text { fear for fail. } \\
\text { Look at the task as imposition. }\end{array}$ & $\begin{array}{l}\text { Surface Strategy: Limit } \\
\text { target to the essentials } \\
\text { through rote learning and } \\
\text { just for reproduction use. }\end{array}$ \\
\hline
\end{tabular}

Source: (Biggs,1987; Biggs et al., 2001) 
Vol.8, Issue 2, pp.22-30, February 2020

Published by ECRTD- UK

Print ISSN: ISSN 2054-6351

Online ISSN: ISSN 2054-636X

\section{What influence SALs?}

Empirically, several researchers have debated the existence of a number of factors that influence the Sudent Approaches to Learning SALs (e.g., Çetin, 2015; Côté, Graillon, et al., 2006; Dinçer \& Devecioglu, 2008; Entwistle \& Tait, 1993). The main factors as described in the 3P Model derive from from the presage factors (Personal and contextual). Variables such as gender, educational background, age, level of education have been reported to influence AAEs (Albaili, 1995; Beckwith, 1991; Cetin, 2015; Dinçer \& Devecioglu, 2008 ; Duff, 2002; Siddiqui, 2006) in different contexts.From the personal characteristics of the students themselves, some variables like gender and year of study has received great attention in the available literature (e.g.,Biggs, 1988; Gow \& Kember, 1990; McDonald et al., 2017). While many investors support the fact that there is significant differences in learning approaches across levels of study (McDonald et al., 2017), the conclusions regarding these differences in gender are unclear (Duff, 2002). In fact, Wilson et al., (1996) reviewed many works having used different instruments such as ASI or SPQ and affirmed no clear consistent conclusion about gender differences. In sum, since SALs are proved affecting the current and the future quality of student's learning, it is important to ask how factors are influencing them.

\section{Objectives of the Study.}

The aim of this study was twofold:

First, examining the dominant approaches to learning among tertiary Moroccan student in an open access university. Second, looking at any significant differences in SALs regarding the level of study and gender as presage factors. Regarding the latter factor, no hypothesis was made since there is inconclusive and no consistent findings about this variable. We expect, in contrary then, that there will be positive difference in SALs by the level of study in Moroccan context. These objectives align with current research trends designed to understand the student experience (Biggs \& Tang, 2011; Shank et al., 2016) as it exists in the Teaching / University Learning paradigm.

\section{METHODOLOGY}

Our research was conducted among Moroccan students of Dhar El Marhaz Faculty of Sciences belonging to Sidi Mohammed Ben Abdellah University (Morocco- Fez). The 300 students target population were all enrolled in the License of Fundament Studies (seem to Bachelor) at different semesters (S2 Year 1; S4 Year 2 and S6 Year 3). Within the framework of this study, we thus carried out a questionnaire made up of two parts. The first part concerned demographic data: Age, gender, Level of study. The second part was developed from our translated and validated R-SPQ-2F version (under publication). The instrument composed of 20 items divided in equal items into the two approaches DA and SA. Each of these dimensions is broken down into two subscales each, namely

Deep Motive (DM) composed of items $\mathrm{N}^{\circ}: 1,5,9,13$ and 17.

Deep Strategy (DS) represented by items $N^{\circ}: 2,6,10,14$ and 18 . 
Surface motive (SM) with items $\mathrm{N}^{\circ}: 3,7,11,15$ and 19.

Surface Strategy (SS) with the elements: $N^{\circ} 4,8,12,16$ and 20.

The measures are noted on a five-point Likert-type scale with ratings ranged from 1 to 5. The final score is calculated according to the following formula: DA score $=$ DM score + SM score and SA score $=$ SM score + SS score. The instrument showed a very good reliability with Alpha Cronbach coefficients of 0.82 and 0.78 respectively for DA and SA factors. A confirmatory factor analysis finding confirm only two main factors model (DA and SA) at the item level. We contented, then, to examine SALs only with the global scores of the two main dimensions DA and SA without examining the scores of the sub-dimensions. In fact. Biggs et al. (2001) considers that in the routine of using the questionnaire, it is the two dimensions DA and SA which are better suited for the users. The data collected were processed under SPSS 22 and descriptive and quantitative statistics were conducted. ANOVA analysis and t-test $t$ test were performed to determine whether there are statistically significant differences on any of the approaches scores on the basis of study level and gender respectively. Significance level was set to 0.05 .

\section{RESULTS}

The Sample profile is shown in the table 2.

Table 2. Composition of the sample regarding level of study and gender.

\begin{tabular}{|l|l|l|}
\hline Variables & Catgories & Number \\
\hline \multirow{4}{*}{ Level of study } & Semester 2 & 100 \\
\cline { 2 - 3 } & Semester 4 & 100 \\
\cline { 2 - 3 } & Semester 6 & 100 \\
\hline \multirow{2}{*}{ Gender } & Male & 162 \\
\cline { 2 - 3 } & Female & 138 \\
\hline
\end{tabular}

\section{Comparison of group means}

The means for the total scores for the entire target population showed a dominance of the surface approach SA compared to the deep approach DA with values of 40.27 (SD $=1.546)$ and 29.10 ( $\mathrm{SD}=1.955)$. Means set of intra-level study scores showed a marked increase in the SA approach $(>40)$ compared to the DA approach $(<30)$ for each level of study. Between levels the SA approach score means is almost stable and ranged between 40,60 (S2) and 40,06 (S4). On the other hand, there was a slight increase for the score mean of DA from S2 to S6 (see Figure2). 


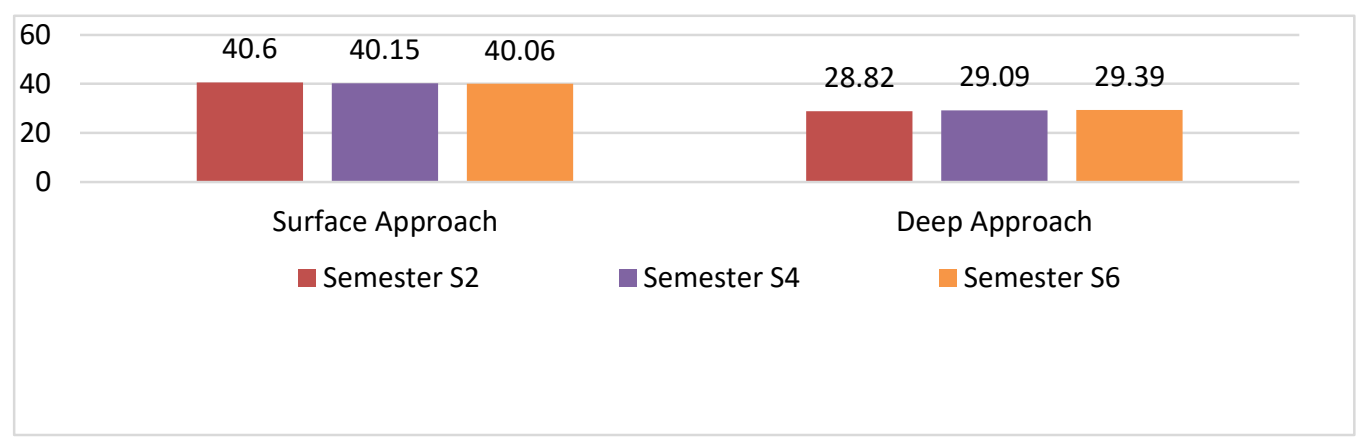

Figure 2.Scores means of learning approaches at different levels of study.

As for the means of the total scores for the learning approaches, they recorded a slight increase in the scores of the DA deep approach over those of the SA surface approach in favor of the female sex (see figure 3).

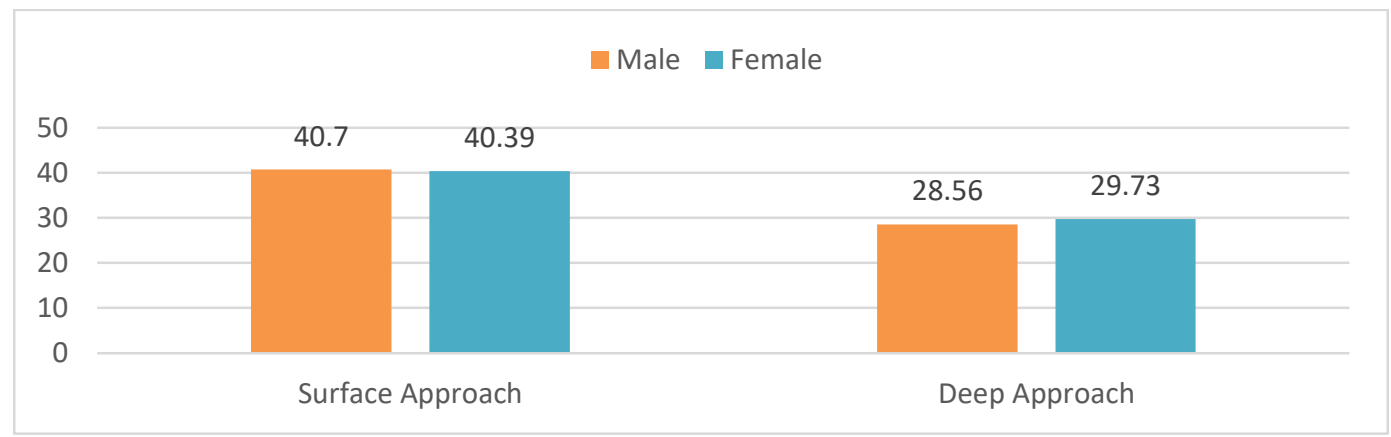

Figure 3.Scores mean of learning approaches by gender.

\section{The Study Level effect}

ANOVA one-way analysis, conducted, found that the effect of a student's study level on his SA surface approach score was statistically insignificant, where $\mathrm{p}$ was of 0.112 for $(\mathrm{F}(2,297)=2,2072, \mathrm{p}<0,05)$. On the contrary, the deep approach scores were moderately significant and had a $p$-value of 0.033 for $(F(2,297)=23,456, p<0,05)$. A post-hoc Tukey test was opted for to look for multiple inter-level comparisons and. The findings showed that this statistical significance of DA was noticed only between the S2 and S6 levels (at least two years of study) with a $\mathrm{p}=0.024$.

\section{Gender effect}

The t-test conducted showed statistical significance between females and males' group. The homogeneity of variance was verified with Levene's Test. We found that females scored DA significantly higher $(M=29,73, S D=1,193)$ than males $(M=28,56, S D$ $=1,611 ; \mathrm{t}(298)=-7,043, \mathrm{p}<.0001)$. 


\section{DISCUSSIONS}

The reliability test and the confirmatory analysis confirmed the construction of the translated version for the tested two-dimensional model and such was proposed by its authors Biggs et al., (2001). The results of the comparison of the means confirm that at the same level of study, first-year (S2) students as well as their second (S4) and third year (S6) colleagues, taken separately, adopt similar learning approaches: Surface Approach. In other words, this could be an indicator of fear of fail, extrinsically motivation, literary memorization, as aforementioned in SA features. This predominant result of the surface approach has been found in other contexts (e.g., Australian context (Biggs, 1987). We suspect that in faculty of sciences especially in courses that support memorization (e.g., geology, biology chemistry), students will continue to memorize material throughout their study, but in a meaningful way. Entwistle and Ramsden (1983, as cited in McDonald et al., 2017) have mentioned that:

"A deep approach in science depends more on operation learning, on relating evidence and conclusion, and on the appropriate use of a certain amount of initial rote learning to master the terminology" (p.209). The differences between levels have shown that S6 students tend to go a little deeper than S2 and S4 students. In fact, and as they progress through the university curriculum, students become more and more aware of their surroundings, passing the basic semesters $S 1$ and S2, begin to take, albeit weak, deep approaches. Our results were similar to what was reported by Biggs (1987) for a study of scientist students. These findings support the claims by previous studies that the motivation gathered from the perception of future career goals and achievement is of great importance to adopt a deep learning approach (Taher \& Jin, 2011). Our research also found that girls take a deeper approach than boys. This result agrees with that of Gledhill and Van der Merwe (1989). This could be related to motivational traits that is girls are more motivated than boys as supported by Lange and Mavondo (2004) study. Some authors stated that in order to promote a deep approach, it would be appropriate for educators take in mind specific strategies based on gender. Other researches on science students has reported that there is no gender difference (Taher \& Jin, 2011; Zeegers, 2001). Even though Others have noted a difference but in favor of the surface approach (Duff, 2002). This shows that there is a divergence of views regarding the effect of gender. Inconsistencies in findings could be explained to some degree by the choice of statistical method (Duff, 2002). This may be also the result of the influence of other presage factors other than gender such as: self-motivation, personality and/or the teaching environment (Hussin et al., 2017).

\section{CONCLUSION}

We can conclude that the Arabic version of the R-SPQ-2F can be used with confidence to evaluate the learning approaches of students in the Moroccan tertiary environment. The preliminary examination showed the dominance of the surface approach. This can be linked both to the person himself (level of study, gender, school history, etc.) and to 
British Journal of Education

Vol.8, Issue 2, pp.22-30, February 2020

Published by ECRTD- UK

Print ISSN: ISSN 2054-6351

Online ISSN: ISSN 2054-636X

the learning context. These approaches are good indicators to assess this context and have feedback to promote the in-depth approach, considered as the preferred approach to achieve good academic results. Our second main objective is to identify the contextual factors which encourage and favor the deep approach. This preliminary study had a limitation concerning the target population which can be regarded as a homogenous group and this may limit the generalizability. Other researches must be taken to investigate other factors influencing SALs in different Moroccan university environments.

\section{References}

Albaili, M. A. (1995). An Arabic Version of the Study Process Questionnaire: Reliability and Validity. Psychological Reports, 77(3_suppl), 1083-1089. https://doi.org/10.2466/pr0.1995.77.3f.1083

Beckwith, J. B. (1991). Approaches to learning, their context and relationship to assessment performance. Higher education, 22(1), 17-30.

Biggs,J.B., Kember, D., \& Leung, D. Y. P. (2001). The revised two-factor Study Process Questionnaire: R-SPQ-2F. British Journal of Educational Psychology, 71(1), 133-149. https://doi.org/10.1348/000709901158433

Biggs, J. B. (1988). Assessing student approaches to learning. Australian Psychologist, 23(2), 197-206. https://doi.org/10.1080/00050068808255604

Biggs, J. B. (1993). From Theory to Practice: A Cognitive Systems Approach. Higher Education Research \& Development, 12(1), 73-85. https://doi.org/10.1080/0729436930120107

Biggs, J. B. (1999). Teaching for quality learning at university (Buckingham, United Kingdom: Society for Research into Higher Education.).

Biggs, J.B., \& Tang, C. (2011). Teaching for quality learning.

Biggs, J. B. (1987). Student approaches to learning and studying. Australian Council for Educational Research.

Cetin, B. (2015). Academic Motivation And Approaches To Learning In Predicting College Students' Academic Achievement: Findings From Turkish And US Samples. Journal of College Teaching \& Learning (TLC), 12(2), 141-150. https://doi.org/10.19030/tlc.v12i2.9200

Côté, D. J., Graillon, A., Waddell, G., Lison, C., \& Noel, M.-F. (2006). L'approche d'apprentissage dans un curriculum médical préclinique basé sur l'apprentissage par problèmes. Pédagogie Médicale, 7(4), 201-212. https://doi.org/10.1051/pmed:2006002

Dinçer, T., \& Devecioglu, Y. (2008). Examining Learning Approaches of Science Student Teachers According to the Class Level and Gender. Online Submission, 54-59.

Duff, A. (2002). Approaches to learning: Factor invariance across gender. Personality and individual differences, 33(6), 997-1010.

Entwistle, N., \& Tait, H. (1993). Approaches to studying and preferences for teaching in higher education: Implications for student ratings. [Conference paper].

Gledhill, R. F., \& Van der Merwe, C. A. (1989). Gender as a factor in student learning: Preliminary findings. Medical Education, 23(2), 201-204. https://doi.org/10.1111/j.1365-2923.1989.tb00887.x 
British Journal of Education

Vol.8, Issue 2, pp.22-30, February 2020

Published by ECRTD- UK

Print ISSN: ISSN 2054-6351

Online ISSN: ISSN 2054-636X

Gow, L., \& Kember, D. (1990). Does higher education promote independent learning? Higher Education, 19(3), 307-322. https://doi.org/10.1007/BF00133895

Hussin, F., Hamed, S., \& Jam, S. M. (2017). Approaches to learning of engineering students: Deep or surface. Int Acad Res J Soc Sci, 3(1), 122-127.

Lange, P., \& Mavondo, F. (2004). Gender and motivational differences in approaches to learning by a cohort of open learning students. Accounting Education, 13(4), 431-448. https://doi.org/10.1080/0963928042000306765

Marton, F., \& Säljö, R. (1976). On qualitative differences in learning : II- outcome as a function of the learner's conception of the task. British Journal of Educational Psychology, 46(2), 115-127. https://doi.org/10.1111/j.20448279.1976.tb02304.x

McDonald, F., Reynolds, J., Bixley, A., \& Spronken-Smith, R. (2017). Changes in approaches to learning over three years of university undergraduate study. Teaching \& Learning Inquiry, 5(2), 65-79. https://doi.org/10.20343/teachlearninqu.5.2.6

Shank, G., Brown, L., \& Pringle, J. (2016). Understanding education research: A guide to critical reading. Routledge.

Siddiqui, Z. S. (2006). Study Approaches of Students in Pakistan: The Revised twofactor Study Process Questionnaire Experience (Occasional Report No 1; p. 13). Higher education commission.

Taher, A. M. M., \& Jin, C. (2011). Assessing learning approaches of Chinese local MBA students: An investigation using the Revised Two-factor Study Process Questionnaire (R-SPQ-2F). Educational Research and Reviews, 6(19), 974. https://doi.org/10.5897/ERR11.152

Tudor, J., Penlington, R., \& McDowell, L. (2010). Perceptions and their influences on approaches to learning. Engineering Education, 5(2), 69-79. https://doi.org/10.11120/ened.2010.05020069

Wilson, K. L., Smart, R. M. and W., \& R.J. (1996). Gender difference in approach to learning in first year psychology students. British Journal of Educational Psychology, 66, 59-71. https://doi.org/10.1111 / j.2044-8279.1996.tb01176.x

Zeegers, P. (2001). Approaches to learning in science: A longitudinal study. British Journal of Educational Psychology, 71(1), 115-132. https://doi.org/10.1348/000709901158424 